\title{
Antibacterial Activity of Honey Against Staphylococcus Aureus and Pseudomonas Aeruginosa Isolated from Infected Wound
}

\author{
Gambo $\mathrm{SB}^{1}$, Ali $\mathrm{M}^{2 *}$, Diso $\mathrm{SU}^{3}$ and Abubakar $\mathrm{NS}^{4}$ \\ ${ }^{1}$ Department of Biological Sciences, Rabiu Musa Kwankwaso College of Advanced and Remedial Studies, Nigeria \\ ${ }^{2}$ Department of Biological Science, Federal University Gusau, Nigeria \\ ${ }^{3}$ Department of Pharmaceutical Technology, School of Technology, Kano State Polytechnic, Nigeria \\ ${ }^{4}$ Department of Medical Laboratory Science, Bayero University Kano, Nigeria
}

*Corresponding author: Muhammad Ali, Department of Biological Science, Federal

Received Date: September 13, 2018

University Gusau, Nigeria.

Published Date: October 01, 2018

\begin{abstract}
Wound infections have been recognized as the most critical problem especially in the presence of foreign materials that increase the risk of serious infection even with relatively small bacterial infection. This study was carried out to determine the antibacterial activity of honey against clinical isolates of Staphylococcus aureus and Pseudomonas aeruginosa obtained from infected wounds. Different concentrations of honey extract $(25,50,75$ and $100 \mathrm{v} / \mathrm{v})$ were tested using agar well diffusion method to determine their antibacterial activity against Staphylococcus aureus and Pseudomonas aeruginosa isolated from infected wounds of patients attending Muhammad Abdullahi Wase Specialist Hospital, Kano. The antibacterial activity of the honey showed that the honey demonstrated antimicrobial activity against the test isolates with higher activity in Staphylococcus aureus (with average zone of inhibition of $15.90 \mathrm{~mm}$ ) than Pseudomonas aeruginosa $(14.63 \mathrm{~mm})$. The minimum inhibitory concentration (MIC) of the extract from this study ranges from $6.25-50 \mathrm{mg} / \mathrm{ml}$ while the minimum bactericidal concentration (MBC) of the extracts ranges from $25-50 \mathrm{mg} /$ $\mathrm{ml}$. Statistical analysis of the results showed that there is no significant different in the activity of honey against the isolates at $\mathrm{p}<0.05$. Based on the results of this study, it is concluded that honey is active against wound bacterial isolates and can be used as a therapy for wound infection.
\end{abstract}

Keywords: Antibacterial activity, Honey, Pseudomonas aeruginosa, Staphylococcus aureus, Wound

\section{Introduction}

Wound infection causes great distress in terms of associated mortality and morbidity, increased length of hospital stays, profound discomfort and significant increase in healthcare cost. Infection in a wound delay healing and may cause wound break down, herniation of the wound and complete wound dehiscence [1]. Therefore, the knowledge of the causative agents of wound infection will be helpful in the control of wound infection and selection of empiric antimicrobial therapy as an infection control measure. Aerobic pathogens such as Staphylococcus aureus, Pseudomonas aeruginosa, and beta haemolytic Streptococci have been most frequently reported as the cause of delay wound healing [2].

Honey is a sweet liquid made by bees using nectar from flowers [3]. Bees first convert the nectar in to honey by a process of regurgitation and evaporation, and then store it as a primary food source in wax honeycombs inside the beehive, which can then be harvested from the hives for human consumption [3]. Honey is antibacterial and can prevent growth of most types of bacteria. The medicinal and antimicrobial activities of honey for wound healing have been introduced for approximately 4,500 years, almost as long as bacteria have been known. Honey has been used as a medicine since ancient times [4,5]. More recently, honey have been reported to have an inhibitory effect to around 60 species of bacteria including aerobes and anaerobes, gram-positives and gram-negatives [6].

The medicinal benefits of honey have gained significant interest as more medical professionals and scientific researchers acknowledge its antibacterial efficiency $[7,8]$. This is due in part to factors such as increased bacterial resistance to first line broad 
spectrum antibiotics, the significant reduction in the number of new antibiotics approved for market and the various complications involved with chronic wounds (e.g., leg and diabetic ulcers) which can lead to amputations and sometimes death [8,9]. Molan [10] reviewed the clinical evidence from various randomized control trials (RCTs) conducted between 2006 and 2011, for the effectiveness of honey-based dressings in healing of wounds. The review revealed that the use of honey and honey-based dressings had increased from 1965 in the year 2006 to 3656 by the year 2011. It was further observed that there was an increase in the range of honey types used as well as the types of wounds that were treated. The review further noted that the above variables (different honeys, wound types and dressings) present challenges which make it difficult for Clinicians to make informed decisions about the clinical efficacy of honey in a systematic manner. It was concluded that proper characterization of the bioactivities of different honey types was required for a systematic and reliable comparison of their potential wound healing performance [10]. Wounds infected with Staphylococcus aureus are quickly rendered sterile by honey. Different types of honey are available depending on the source of nectar used in its production. The source of the nectar determines the degree of antibacterial activity of the honey [11]. The aim of the study was to determine the antibacterial activity of honey against Staphylococcus aureus and Pseudomonas aeruginosa isolated from infected wound of patients attending Muhammad Abdullahi Wase Specialist Hospital Kano

\section{Materials and Methods}

\section{Study area}

The study area is Kano metropolis, samples from infected wound patients were collected from Muhammad Abdullahi Wase Hospital in the state capital. Kano State is a state located in North-Western Nigeria and one of the largest State of the Nigerian Federation, it is bordered by Katsina State to the North-West, Jigawa State to the North-East, Bauchi State to the South-East and Kaduna State to the South-West. Kano is located on $12^{\circ} \mathrm{N}$ and $8^{\circ} 30^{\prime} \mathrm{E}$. It has a total area of $20,131 \mathrm{~km}^{2}$. The urban area covers $137 \mathrm{~km}^{2}$ and comprises of six LGAs-Kano municipal, Fagge, Dala, Gwale, Tarauni and Nassarawa with population of 2,163,25 as at 2006 [12].

\section{Ethical clearance}

Ethical approval (Issue number: HMB/GEN/488/Vol. I) was obtained from Health Service Management board (HSMB) Kano State based on the consent of Muhammad Abdullahi Wase Specialists Hospital (MAWSH) Ethical Committees.

\section{Sample collection}

The swap sticks containing a total of 52 samples from infected wound were collected from Microbiology laboratory of Abdullahi Wase Special Hospital Kano State for isolation and characterization of Staphylococcus aureus and Pseudomonas aeruginosa.

\section{Isolation and identification of test organisms}

The samples from swap containing pus from patients were inoculated onto the surface of nutrient agar plate and incubated for 24 hours at $37^{\circ} \mathrm{C}$. Each colony was isolated in a pure form by sub culturing for further studies and identification. Distinctive morphological properties of each pure culture such as colony form, elevation of colony and colony margin were observed. Further microbial identification (Gram staining and biochemical characterization including catalase, coagulase and oxidase tests) was based on the methods of Holt et al. [13].

\section{Confirmatory test of natural (raw) honey}

A spoonful of honey was added to a glass of warm water, stirred slowly. This helped to find whether it dissolved in the water. Most raw honey sticks together and sunk as a solid lump or remains stuck as a lump on the spoon. A fire was set to a candle wick dipped in honey to check for added water in the honey which might prevented the honey from burning [10].

\section{Preparation of honey concentration}

Natural (raw) and processed honey was used. Different concentrations of each honey contributing $25 \% \mathrm{v} / \mathrm{v}, 50 \% \mathrm{v} / \mathrm{v}$, $75 \% \mathrm{v} / \mathrm{v}$ and $100 \% \mathrm{v} / \mathrm{v}$ were made in sterile distilled water. This was done by dissolving the respective volumes of honey into corresponding volumes of sterile distilled water [10].

\section{Antibacterial activity of honey}

The agar well diffusion technique was used to screen for antibacterial activity of honey. The standard inoculums $(0.5$ MacFarland Standard) were introduced into the surface of the Mueller Hinton agar plate and a sterile glass was used for even distribution over the media. Five wells were made using a sterile cork borer and each well was filled with different concentrations $(25,50,75$ and $100 \mathrm{v} / \mathrm{v})$ of the honey. The plates were incubated at $37^{\circ} \mathrm{C}$ for $24 \mathrm{hrs}$ and observed for zone of inhibitions. This in-vitro experiment was compared with the use of $50 \mathrm{mg} / \mathrm{ml}$ Gentamicin (Micro lab) as control. The antibacterial activity was expressed as the mean diameter of inhibition zone $(\mathrm{mm})$ produced by the honey [14].

\section{Determination of Minimum Inhibitory Concentration (MIC) of the extracts}

The MIC of the honey was determined using broth dilution technique. Two-fold serial dilutions of the honey were prepared by adding $2 \mathrm{ml}$ of $100 \mathrm{v} / \mathrm{v}$ of the honey into a test tube containing $2 \mathrm{ml}$ of Nutrient broth, thus producing solution containing $50 \mathrm{v} / \mathrm{v}$ of the extract. The process continues serially up to test tube No. 5, hence producing the following concentrations; $50,25,12.5,6.253 .125 \mathrm{v} / \mathrm{v}$. Test tube No. 6 do not contain extracts and serve as negative control. Exactly $0.5 \mathrm{ml}$ of $0.5 \mathrm{McF}$.rland equivalent standards of test organisms were introduced into the test tubes and incubated at 37 ${ }^{\circ} \mathrm{C}$ for 24 hours. After incubation the test tubes were observed for growth by checking for turbidity [15].

\section{Determination of Minimum Bactericidal Concentration (MBC) of the extracts}

From the result of MIC, the test tubes that did not show visible growth were used for MBC determination. About $0.1 \mathrm{ml}$ was aseptically transferred onto the surface of Mueller Hinton agar plates. The plates were incubated at $37^{\circ} \mathrm{C}$ for 24 hours. The MBC of the extracts was recorded as the lowest concentration of the extract that had less than 99\% growth on Mueller Hinton agar plates [19]. 


\section{Statistical Analysis}

The data of average zone of inhibition produced by the isolates against the honey used was analyzed using one way Analysis of Variance (ANOVA) with the aid of statistical program SPSS (Statistical package for Social Sciences) version 21.0. Significance level for the differences was set at $\mathrm{p}<0.05$.

\section{Result}

\section{Isolation and identification of test organisms}

The result of identification of the test isolates is represented in Table 1. The tests conducted include Gram staining, Catalase test, Coagulase test, Oxidase test and Mannitol salt agar test for Staphylococcus aureus. The $S$. aureus was found to be positive for Catalase and coagulase test but negative for oxidase test. On the other hand, $P$. aeruginosa was positive for catalase and oxidase tests but negative for coagulase test (Table 1).
Table 1: Gram staining and Biochemical characterization of the isolates.

\begin{tabular}{|c|c|c|c|c|c|}
\hline Organisms & $\begin{array}{c}\text { Gram } \\
\text { Staining }\end{array}$ & $\begin{array}{c}\text { Catalase } \\
\text { Test }\end{array}$ & $\begin{array}{c}\text { Coagulase } \\
\text { Test }\end{array}$ & $\begin{array}{c}\text { Oxidase } \\
\text { Test }\end{array}$ & $\begin{array}{c}\text { Mannitol } \\
\text { Growth }\end{array}$ \\
\hline S. aureus & $\begin{array}{c}\text { Positive } \\
\text { cocci }\end{array}$ & + & + & - & + \\
\hline $\begin{array}{c}P . \\
\text { aeruginosa }\end{array}$ & $\begin{array}{c}\text { Negative } \\
\text { rod }\end{array}$ & + & - & + & NA \\
\hline
\end{tabular}

KEY: + = Positive, - = Negative, NA = Not Applicable

\section{Antibacterial activity of honey}

The antibacterial activity of different honey concentration against Staphylococcus aureus recovered from different wound samples is presented in Table 2. The result showed that higher zone of inhibition was shown by isolate $\mathrm{S}_{4} 23.3 \mathrm{~mm}$ at concentration of $100 \mathrm{v} / \mathrm{v}$. Isolate $S_{1}$ was found to be more resistant to the honey. Zones of inhibition recorded by the control ranged from $15-22 \mathrm{~mm}$ (Table 2).

Table 2: Antibacterial Activity of Different Honey Concentration against Staphylococcus aureus recovered from different wound samples with standard error.

\begin{tabular}{|c|c|c|c|c|c|}
\hline \multicolumn{7}{|c|}{ Concentration (v/v)/Zone of Inhibition (mm) } \\
\hline Organisms & 25 & 50 & 75 & 100 & $17.6 \pm 0.23^{\mathrm{c}}$ \\
\hline$S_{1}$ & $06.0 \pm 0.00^{\mathrm{a}}$ & $10.3 \pm 0.27^{\mathrm{b}}$ & $13.6 \pm 0.27^{\mathrm{b}}$ & $20.6 \pm 0.23^{\mathrm{b}}$ & 15 \\
\hline $\mathrm{S}_{2}$ & $13.3 \pm 0.27^{\mathrm{a}}$ & $16.6 \pm 0.23^{\mathrm{a}}$ & $22.3 \pm 0.27^{\mathrm{b}}$ & $21.3 \pm 0.27^{\mathrm{b}}$ & 22 \\
\hline $\mathrm{S}_{3}$ & $12.3 \pm 0.27^{\mathrm{a}}$ & $14.6 \pm 0.27^{\mathrm{a}}$ & $17.6 \pm 0.23^{\mathrm{b}}$ & $23.3 \pm 0.27^{\mathrm{b}}$ & 21 \\
\hline$S_{4}$ & $13.3 \pm 0.27^{\mathrm{a}}$ & $14.3 \pm 0.27^{\mathrm{a}}$ & $18.6 \pm 0.27^{\mathrm{b}}$ & 21 \\
\hline
\end{tabular}

Key: Values having different superscript in the same row are considered significantly different at probability level of $p<0.05$. S1 $=S$. aureus recovered from trauma wound, $\mathrm{S}_{2}=S$. aureus recovered from surgical wound, $\mathrm{S}_{3}=S$. aureus recovered from sepsis wound, $\mathrm{S}_{4}$ $=S$. aureus recovered from bite wound.
The antibacterial activity of different honey concentration against Pseudomonas aeruginosa recovered for different wound samples is presented in Table 3. The result showed that higher zone of inhibition was shown by isolate $\mathrm{P}_{4} 20.3 \mathrm{~mm}$ at concentration of $100 \mathrm{v} / \mathrm{v}$. Zones of inhibition recorded by the control ranged from $17-19 \mathrm{~mm}$

(Table 3).

Table 3: Antibacterial Activity of Different Honey Concentration against Pseudomonas aeruginosa recovered from different wound samples with standard error.

\begin{tabular}{|c|c|c|c|c|c|}
\hline \multicolumn{5}{|c|}{ Concentration (v/v)/ Zone of inhibition (mm) } \\
\hline Organisms & $\mathbf{2 5}$ & $\mathbf{5 0}$ & $\mathbf{7 5}$ & $\mathbf{1 0 0}$ & $14.6 \pm 0.23^{\mathrm{b}}$ \\
\hline $\mathrm{P}_{1}$ & $10.6 \pm 0.23^{\mathrm{a}}$ & $10.3 \pm 0.27^{\mathrm{a}}$ & $11.3 \pm 0.27^{\mathrm{a}}$ & $18.6 \pm 0.23^{\mathrm{b}}$ & 17 \\
\hline $\mathrm{P}_{2}$ & $12.3 \pm 0.27^{\mathrm{a}}$ & $14.6 \pm 0.23^{\mathrm{a}}$ & $15.3 \pm 0.27^{\mathrm{a}}$ & $20.6 \pm 0.23^{\mathrm{b}}$ & 19 \\
\hline $\mathrm{P}_{3}$ & $13.3 \pm 0.27^{\mathrm{a}}$ & $15.6 \pm 0.23^{\mathrm{a}}$ & $18.6 \pm 0.23^{\mathrm{b}}$ & $20.3 \pm 0.27^{\mathrm{a}}$ & 17 \\
\hline $\mathrm{P}_{4}$ & $12.6 \pm 0.23^{\mathrm{a}}$ & $16.3 \pm 0.27^{\mathrm{a}}$ & $18.6 \pm 0.27^{\mathrm{b}}$ & 17 \\
\hline
\end{tabular}

Key: Values having different superscript in the same row are considered significantly different at probability level of $\mathrm{p}<0.05 . \mathrm{P}_{1}$ $=P$. aeruginosa recovered from trauma wound, $\mathrm{P}_{2}=P$. aeruginosa recovered from surgical wound, $\mathrm{P}_{3}=P$. aeruginosa recovered from sepsis wound, $\mathrm{P}_{4}=$ P. aeruginosa recovered from bite wound.

\section{MIC and MBC of honey}

The minimum inhibitory concentration (MIC) of honey is represented in Table 4 which showed dilutions of various concentrations of the honey against test organisms. Lower MIC was recorded in isolate $\mathrm{S}_{2}, \mathrm{~S}_{3}, \mathrm{~S}_{4}$ and P1 (12.5v/v) while highest 
MIC value was recorded in isolate $S_{1}, P_{2}$, and $P_{3}(50 v / v$ each). The minimum bactericidal concentration (MBC) of the honey showed that the honey can kill the test isolates at concentration of 12.5$50 \mathrm{v} / \mathrm{v}$ (Table 4).

Table 4: MIC and MBC of the honey against the isolates.

\begin{tabular}{|c|c|c|}
\hline \multicolumn{3}{|c|}{ MIC/MBC (mg/ml) } \\
\hline Isolates & Aqueous Extract & Methanol Extract \\
\hline $\mathrm{S}_{1}$ & $25 / 50$ & $12.5 / 50$ \\
\hline $\mathrm{S}_{2}$ & $6.25 / 25$ & $6.25 / 25$ \\
\hline $\mathrm{S}_{3}$ & $6.25 / 50$ & $6.25 / 25$ \\
\hline $\mathrm{S}_{4}$ & $6.25 / 50$ & $6.25 / 25$ \\
\hline $\mathrm{P}_{1}$ & $6.25 / 50$ & $12.5 / 25$ \\
\hline $\mathrm{P}_{2}$ & $25 / 50$ & $12.5 / 50$ \\
\hline $\mathrm{P}_{3}$ & $25 / 50$ & $12.5 / 50$ \\
\hline $\mathrm{P}_{4}$ & $12.5 / 50$ & $6.25 / 50$ \\
\hline
\end{tabular}

\section{Discussion}

In the study, honey sample showed the antimicrobial activity against Staphylococcus aureus and Pseudomonas aeruginosa. Higher activity was shown by Staphylococcus aureus compared to Pseudomonas aeruginosa. This is due to emerging resistivity of Pseudomonas aeruginosa. The results of this study were in agreement with Willix et al. [16] who found that honey inhibited the growth of S. aureus, E. coli and Pseudomonas sp. and also in agreement with Bilal et al. [17] who found honey exhibited a fairly good antimicrobial activity against both Gram-negative and -positive bacteria and a remarkable activity was observed with $P$. aeruginosa and S. aureus. From the result represented on table 4.5 and 4.6, it was observed that the zone of inhibition was increased with the concentration of the honey i.e. an increase in the honey concentration increases the zone of inhibition. Glucosidase levels in honey may vary depending on bee health and its diet [18]. However, the amount of hydrogen peroxide produced in a sample of honey is not only determined by glucosidase levels, honey can contain catalase, peroxidases and antioxidant as gallic acid and caffeic acid, hydrogen peroxide can degrade or interfere with their ability to damage the cell's bacterium $[19,20]$. Some reports show that the presence of methylglyoxal (MGO) can modify some honey proteinaceous compounds and therefore can affect the glucosidase activity [21]. The level of peroxide in honey is determined also by the presence of catalase, which originates from the pollen of plants [19]. The amount of hydrogen peroxide is affected by light, temperature and oxygen, which might vary according to the processing and storage conditions of honey. If these are not adequate, the main enzyme which generates hydrogen peroxide is inactivated and consequently the effect of hydrogen peroxide as antibacterial factor could be reduced [22].

Considering studies by Chen [23] on honey samples heated at temperatures $45{ }^{\circ} \mathrm{C}$ for $8 \mathrm{~h}$ and a filtering process, it may be concluded that the amount of hydrogen peroxide is not indicator of antimicrobial activity but is related to the stability of hydrogen peroxide when honey is subjected to heating and filtration, but the researches shows that more observations should be made to corroborate this observation. In some cases, the antibacterial activity is due entirely to the non-peroxide components such as acidity, osmolarity, flavonoids, phenolic compounds and lysozyme [24]. An advantage of nonperoxide antibacterial activity is that it remains intact after storage of honey for long periods of time [25] and does not change with different conditions of heat and light $[25,26]$. In relation to non-peroxide and non-active compounds of honey, Yatsunami \& Echigo [27] found that low pH honey, in addition to the high honey osmolarity, were responsible for the antibacterial activity.

Different studies have claimed that honeys contain bioactive compounds such as lysozyme, a well-known antibacterial agent [28], however some honeys do not have lysozyme activity [25]. In addition, the antibacterial flavonoid pinocembrin is present in honey but its concentration and contribution to the non-peroxide antibacterial activity of honey is not significant [25]. On the other hand, volatile substances with antibacterial activity have also been isolated from honeys [29], but their quantitative contribution to the antibacterial action of the honey has not been examined. Other substances with non-peroxide activity were extracted by organic solvents from honeys, but it was not possible to identify the chemical nature of these substances [30].

Taormina et al. [31] tested antibacterial activity from six floral sources against Escherichia coli 0157H7, Salmonella thyphimurium, Shigella sonnei, Listeria monocytogenes, S. aureus and Bacillus cereus, by the disc diffusion test and they showed that the development of inhibition zones depends on the concentration of honey used in the test as well as the tested pathogen. Growth of B. cereus was least affected by honey diluted $25 \%$ when compared with others. It has been shown that honeys with low levels of phenol and tocopherol had the highest antibacterial activity against clinical isolates of S. aureus, et al. [32]. In Argentina, studies were carried out to evaluate the antibacterial activity of multifloral honey from the stingless bees (Plebeia wittmanni and Tetragonisca angustula fiebrigi). It was shown that $E$. coli was inhibited only by antibacterial effect of honey from $P$ wittmanni [33].

The results of antibacterial activity of honey from this study against $S$. aureus and $P$. aeruginosa as inconformity with that of Molan [10] who found the S. aureus, as one of the bacterial species most susceptible to the antibacterial activity of honey. These might be due to the osmotic effect, the effect of $\mathrm{pH}$ and the sensitivity of these organisms to hydrogen peroxide which represented an 'inhibine', factor in honey [34]. On the other hand, the results of antibacterial activity of honey against test isolates contradict some findings. The result of this study is contrary to that of Abd-el et al. [35] who showed that honey have a greater inhibitory effect on isolated gram-negative bacteria (P. aeruginosa, Enterobacter spp. and Klebsiella) when compared to Gram positive. Also El-Sukhon et al. [36] showed gram negative bacteria to be more sensitive to action of honey than Gram-positive bacteria. Different concentrations of honey were able to inhibit the growth of both Staphylococcus aureus and Pseudomonas aeruginosa. The minimum inhibitory concentration (MIC) of the honey against the test isolates ranges $12.5 \mathrm{v} / \mathrm{v}$ to $50 \mathrm{v} / \mathrm{v}$. Isolate $\mathrm{S}_{1}$ is found to have high MIC value $(50 \mathrm{v} / \mathrm{v})$ compare to the rest. The isolate is suspected to be Methicillin resistant due to resistivity to amoxicillin and Ampicillin. Similar findings had been reported from various researchers. 
Cooper [37] has reported that manuka honey had MIC of less than $10 \%$ against 17 strains of $P$. aeruginosa from infected wounds, and honeys which have a MIC of $10-20 \%$, can be expected to be effective in preventing growth of Pseudomonas, followed by $E$. coli and $S$. aureus and these result is in agreement with Willix et al. [16] who found the MIC (minimum inhibitory concentration) of the honeys to range from $1.8-10.8 \%(\mathrm{v} / \mathrm{v})$, indicating that the honeys had sufficient antibacterial potency to stop bacterial growth if diluted at least nine times and up to 56 times in the presence of $S$. aureus.The high antibacterial effect of honey sample in diffusion test and the low MIC may be attributable to the presence of glucose oxidase, which is activated by dilution in water resulting in the production of hydrogen peroxide which is toxic to bacteria [38].

\section{Conclusion}

In this study it has been found that Staphylococcus aureus and Pseudomonas aeruginosa can be identified using Gram staining and simple biochemical test such as catalase, coagulase and oxidase tests. Finding of this study indicated that honey is active against Staphylococcus aureus and Pseudomonas aeruginosa isolated from infected wound. The antibacterial activity of honey is largely due to certain antibacterial properties it possessed. These include high osmotic pressure, low water activity, low PH and possession of certain Gluco-oxidase enzymes which produce aseptic substances such as Hydrogen peroxide. It is concluded that honey and stem bark extract of Vitex doniana can be used as a therapy for wound infection.

\section{Acknowledgement}

None.

\section{Conflict of Interest}

No conflict of interest.

\section{References}

1. Rubin RH (2006) Surgical wound infection: epidemiology, pathogenesis, diagnosis and management. BMC Infect Dis 6: 171-172.

2. Brook I (1996) Aerobic and anaerobic microbiology of necrotizing fasciitis in children. Pediatr Dermatol 13(4): 281-284

3. Mundo M, Padilla- Zakour OI, Worobo RW (2004) Growth inhibition of foodborne pathogens and food spoilage organisms by select raw honey. Int J Food Microbiol 97(1): 1-8.

4. Maeda Y, Loughrey A, Earle JA, Millar BC, Rao JR, et al. (2008) Antibacterial activity of honey against community-associated methicillin-resistant Staphylococcus aureus (CA-MRSA). Complement Ther Clin Pract 14(2): 77-82.

5. Fatemeh Ahmadi-Motamayel F, Seyedeh Sare Hendi, Mohammad Yusof Alikhani, Zahra Khamverdi (2013) Antibacterial Activity of Honey on Cariogenic Bacteria. J Dent (Tehran) 10(1): 10-15.

6. Halawani E, Shohayeb M (2011) Survey of the antibacterial activity of Saudi and some international honeys. J Microbiol Antimicrob 3(4): 94-101.

7. Irish J, Carter D, Blair S (2005) Honey kills some of our most dangerous microbial enemies. In Proceedings of the $39^{\text {th }}$ Congress of the International Federation of Beekeepers, Dublin, Ireland, pp. 21-26.

8. Joshua B, Keshu ND (2015) Comparing the Antibacterial and Functional Properties of Cameroonian and Manuka Honeys for Potential Wound Healing-Have We Come Full Cycle in Dealing with Antibiotic Resistance?. Molecules 20(9): 16068-16084.
9. Cooke J (2014) When antibiotics can be avoided in skin inflammation and bacterial colonization? A Review of topical treatments. Curr Opin Infect Dis 27(2): 125-129.

10. Molan P (2011) The evidence and the rationale for the use of honey as a wound dressing. Wound Practice and Research 19(4): 201-221.

11. Hyungjae L, Churey JJ, Worobo RW (2008) Antimicrobial activity of bacterial isolates from different floral sources of honey. Int J Food Microbiol 126(1-2): 240-244

12. National Population Commission (NPC) (2006) National Population Census result, Abuja, Nigeria.

13. Holt JG, Krieg NR, Sneath PA, Stanley JT, Williams ST (1994) Bergey's manual of systematic bacteriology. ( $9^{\text {th }}$ edn), Williams \& Wilkins Co. Baltimore, Maryland, USA, p.786.

14. Ali M, Yahaya A, Zage AU, Yusuf ZM (2017) In-vitro Antibacterial Activity and Phytochemical Screening of Psidium guajava on Some Enteric Bacterial Isolates of Public Health Importance. Journal of Advances in Medical and Pharmaceutical Sciences 12(3): 1-7.

15. Ahmed I, Beg AZ (2001) Antimicrobial and phytochemical studies on 45 Indian Medicinal plants against multi-drug resistance human pathogens. J Ethnopharmacol 74(2): 113-123.

16. Willix DJ, Molan PC, Harfoot CG (1992) A comparison of the sensitivity of wound-infecting species of bacteria to the antibacterial activity of Manuka honey and other honey. J Appl Bacteriol 73(5): 388-394.

17. Bilal AN, Molan PC, Sallal AK (1998) Antimicrobial activity of honey onselected microorganisms: A preliminary study. Biomed Res (India) 9 $51-54$

18. Alaux C, Ducloz F, Crauser D, Leconte Y (2010) Diet effects on honeybee immunocompetence. Biol Lett 6(4): 562-565.

19. Weston R (2000) The contribution of catalase and other natural products to the antibacterial activity of honey: a review. Food Chem 71(2): 235239.

20. Pyrzynska K, Biesaga M (2009) Analysis of phenolic acids and flavonoids in honey. Trens Anal Chem 28(7): 893-902.

21. Majtan J, Kaludiny J, Bohova J, Kohutova L, Dzurova M, et al. (2012) Methylglyoxal-induced modifications of significant Honeybee proteinous components in manuka Honey: possible therapeutics implications. Fitoterapia 83(4): 671-677

22. Dustman JH (1970) Antibacterial effect honey. Apiacta 14: 7-11.

23. Chen C, Campbell LT, Blair SE, Carter DA (2012) The effect of standard heat and filtration processing procedures on antimicrobial activity and hydrogen peroxide level in honey. Front Microbiol 3: 265.

24. Allen KL, Molan PC, Reid M (1991) A survey of the antibacterial activity of some New Zealands Honeys. J Pharm Pharmacol 43(12): 817-822.

25. Bogdanov S (1989) Determination of pinocembrin in honey using HPLC J Agric Res 28: 55-57.

26. Gonnet M, Lavie P (1960) Influence du chaufage sur le facteur antibiotic du miel. Annales de l'Abeille 3(4): 349-364

27. Yatsunami K, Echigo T (1984) Antibacterial activity of honey and roya jelly. Honeybee Sci 5: 125-130.

28. Estrada H, Gamboa Mdel M, Arias ML, Chaves C (2005) Evaluation of the antimicrobial action of honey against Staphylococcus aureus, Staphylococcus epidermidis, Pseudomonas aeruginosa, Escherichia coli, Salmonella enteritidis, Listeria monocytogenes and Aspergillus niger. Evaluation of its microbiological charge. Arch Latinoam Nutr 55(2) 167-171.

29. Toth G, Lemberkovics E, Kutasi-SzaboJ (1987) The volatile components of some Hungarian honeys and their antimicrobial effects. Am Bee J 127:96-497.

30. Radwan SS, El-Essawy AA, Sarhan MM (1984) Experimental evidence for the occurrence in honey of specific substances active against microorganisms. Zentralblatt f ur Mikrobiologie 139: 249-255. 
31. Taormina PJ, Niemira BA, Beuchat LR (2001) Inhibitory activity of honey against foodborne pathogens as influenced by the presence of hydrogen peroxide and level of antioxidant power. Int J Food Microbiol 69(3): 217225.

32. Adetuyi FO, Ibrahim TA, Jude-Ojei Ogundahunsi GA (2009) Total phenol, tocopherol and antibacterial quality of honey Apis mellifera sold in Owo community, Ondo State, Nigeria. Afr J Biotechnol 8(7): 1305-1309.

33. Sgariglia MA, Vattuone MA, Sampietro Vattuone MM, Soberon JR, Sampitro DA (2010) Properties of honey from Tetragonisca angustula fiebrigi and Plebeia wittmanni of Argentina. Apidologie 41(6): 667-675.

34. Baltrusaityte V, Rimantas Venskutonis P, Čeksteryte V (2007) Antibacterial activity of honey and beebread of different origin against S. aureus and S. epidermidis. Food Technol Biotechnol 45(2): 201-208.
35. Abd-El AM, El-Hadidy NB, El-Mashad NB, El-Sebaie AH (2007) Antimicrobial effect of bee honey in comparison to antibiotics of organisms isolated from infected burns. Anns burns fire disaster 20(2): 83-88.

36. El-Sukhon S, Harfeil NA, Salal AK (1994) Effect of honey on bacteris growth and spore's germination. Journal of food protection 57(10): 918920

37. Cooper R, Molan P (1999) The use of honey as an antiseptic in managing Pseudomonas infections. J Wound Care 8(4): 161-164.

38. Stinson EE, Subers MH, Petty J, White JW (1960) The composition of honey. V. Separation and identification of the organic acids. Arch Biochem Biophys 89: 6-12. 